\title{
A STUDY OF AEROBIC BACTERIAL PROFILE AND ANTIBIOTIC RESISTANCE IN PATIENTS WITH DIABETIC AND NON-DIABETIC WOUND INFECTIONS
}

\author{
Vinod Birra1, Anil Kumar Hanumanthu², Srinivas Budati ${ }^{3}$, Narasimha Murty S4, Ramesh Hanumanthu5, Sudheer Tulasi ${ }^{6}$ \\ ${ }^{1}$ Associate Professor, Department of Dentistry, Rajiv Gandhi Institute of Medical Sciences (RIMS), Srikakulam, Andhra Pradesh. \\ ${ }^{2}$ Assistant Professor, Department of General Medicine, Rajiv Gandhi Institute of Medical Sciences (RIMS), Srikakulam, Andhra Pradesh. \\ ${ }^{3}$ Tutor, Department of Microbiology, Rajiv Gandhi Institute of Medical Sciences (RIMS), Srikakulam, Andhra Pradesh. \\ ${ }^{4}$ Assistant Professor, Department of General Medicine, Rajiv Gandhi Institute of Medical Sciences (RIMS), Srikakulam, Andhra Pradesh. \\ 5Tutor, Department of ENT, Rajiv Gandhi Institute of Medical Sciences (RIMS), Srikakulam, Andhra Pradesh. \\ ${ }^{6}$ Assistant Professor, Department of Orthopaedics, Rajiv Gandhi Institute of Medical Sciences (RIMS), Srikakulam, Andhra Pradesh.
}

\section{ABSTRACT}

\section{BACKGROUND}

Diabetic foot infections can be devastating, often eventuating in hospitalisation and occasionally a lower extremity amputation. Over the past three decades, studies have provided data with which evidence-based guidelines were developed. These have used a methodical approach to evaluate the available evidence on determining which diabetic foot wounds are infected, how to culture these wounds, what local care and surgical procedures are most appropriate and how to approach providing optimal antibiotic therapy.

\section{MATERIALS AND METHODS}

This prospective study included 71 and 53 consecutive patients with diabetes and non-diabetics respectively with various wound infections; exudates were inoculated on nutrient agar, blood agar, MacConkey agar and chocolate agar plates for the isolation of aerobic bacteria and antibiotic susceptibility testing was performed.

\section{RESULTS}

A total number of ulcer samples analysed were 255,318 from Diabetes Mellitus (DM) and Non-Diabetes Mellitus (NDM) respectively. The isolates of culture positive were $71(27.84 \%)$ and $53(16.67 \%)$. In diabetic group more resistance were penicillin (100\%), azithromycin (87.32\%), cefotaxime (88.73\%), erythromycin (92.96\%) and polymyxin B (78.87\%). In non-diabetic group, more resistance were penicillin (98.11\%), cefotaxime (75.47\%) and erythromycin (88.68\%).

\section{CONCLUSION}

Rate of antibiotic resistance was more in diabetic persons. They are prone for variety of infections when compared with non-diabetic mellitus. In both groups aztreonam, amikacin, gentamicin, tetracycline, vancomycin and imipenem were the most useful antibiotics.

\section{KEYWORDS}

Bacterial Profile, Diabetic, Non-Diabetic, Wound Infections, Drug Resistance.

HOW TO CITE THIS ARTICLE: Birra V, Hanumanthu AK, Budati S, et al. A study of aerobic bacterial profile and antibiotic resistance in patients with diabetic and non-diabetic wound infections. J. Evolution Med. Dent. Sci. 2016;5(98):7180-7184, DOI: 10.14260/Jemds/2016/1625

\section{BACKGROUND}

Insulin is an enzyme secreting by pancreas gland. When insulin decreased in secretion or action, that disease is called as diabetes. In $21^{\text {st }}$ century diabetic and cardiovascular disease are emerging infections to mankind. Approximately, 320 million persons will be diabetic in end of 2025.[1] Diabetic persons are also associated with reduced immunity system like decreased response of T-cell and its activity, etc. ${ }^{[2-4]}$ The epidemiology of diabetic chronic wound infections due to countless studies surveying the associated microorganisms. Although, the specific percentages differ from study to study,

Financial or Other, Competing Interest: None.

Submission 04-11-2016, Peer Review 29-11-2016,

Acceptance 04-12-2016, Published 08-12-2016.

Corresponding Author:

Srinivas Budati,

C-6, RIMS Quarters,

RIMS Campus, Balaga,

Srikakulam-532001,

Andhra Pradesh, India.

E-mail:vasmedmicro@yahoo.com

DOI: $10.14260 /$ jemds $/ 2016 / 1625$ the most predominant aerobes are Staphylococcus aureus, coagulase-negative Staphylococci, Streptococcus species, Enterococcus species, Corynebacterium species, Enterobacteriaceae and Pseudomonas aeruginosa. Multidrug Resistant Organisms (MDRO) are defined as microorganisms that are resistant to two or more classes of antimicrobial agents.[5] For diabetics, the risk factors associated with acquiring an MDRO infection have been identified and include previous antibiotic therapy and its duration, frequency of hospitalisation, duration of hospital stays, osteomyelitis and proliferative retinopathy.[6,7,8] These risk factors would suggest that MDRO infection rates would be higher in the diabetic population versus the non-diabetic population; there have been no reports directly comparing the rates of MDRO infections in diabetic versus non-diabetic wounds. The goal of this study was to determine if infections with MDRO occurred more in the diabetic population, and if so which bacterial species were most prevalent. Approximately, one-fourth of people with diabetes will develop an ulcer during their lifetime and as many as half of these ulcers will become infected.[9,10] Diabetic foot ulcers are colonized by pathogenic bacteria that may predispose a susceptible patient to a lower extremity infection, defined as the invasion and multiplication of 
microorganisms in body tissues associated with tissue destruction or host inflammatory responses. [11]

In people with diabetes wounds/ulcers, several factors such as inappropriate antibiotic treatment, the chronic nature of the wound and frequent hospital admission can influence the presence of multidrug-resistant microorganisms in the ulcer. Recurrent pathogenic MDR strains can cause amputation, increased hospital stay, morbidity and mortality in diabetic persons. Therefore, the aim of the present study was to evaluate the bacteriological profile and drug resistance association of wound infections with and of diabetic at Rajiv Gandhi Institute of Medical Sciences (RIMS), Srikakulam, Andhra Pradesh in order to determine the relative frequencies of pathogens from wound infections and to study the in vitro antibiotic resistance.

\section{MATERIALS AND METHODS \\ Study Design}

This prospective study included 71 and 53 consecutive patients with diabetes and non-diabetic respectively with various wound infection, who were Outpatient (OP) and Inpatient (IP) attended departments like General Medicine, Dental, Surgery, Orthopaedics, ENT of the Rajiv Gandhi Institute of Medical Sciences, Srikakulam between January 2016 and October 2016. The Hospital is a 500-bedded tertiary care hospital utilised by people from most backward area of Srikakulam district and its surrounding areas. Demographic and lesion data including all types of wound infection of diabetic and non-diabetic patients, features of the lesion and location of the lesion were recorded for each patient.

\section{Characterisation of Bacterial Isolates}

Culture specimens were collected using sterile cotton swabs. To eliminate the possibility of isolating colonising bacteria, all type of wounds were included in the study. After cleaning the wound site with sterile normal saline, swab samples were collected aseptically and transported immediately in Stuart medium to laboratory. The specimens were inoculated on blood agar, chocolate agar, MacConkey agar and nutrient agar plates, incubated aerobically at $37^{\circ} \mathrm{C}$ for 24 hours. The isolates were further confirmed by gram-staining, colony morphology, hanging drop, an oxidase test, catalase test, slide and tube coagulase test and various biochemical tests.[12] In this study, anaerobic bacteria excluded.

\section{Antibiotic Sensitivity Testing}

Antibiotic sensitivity testing was performed by standard Kirby Bauer disk diffusion method followed to the Clinical and Laboratory Standards Institute (CLSI) guidelines.[13] The antibiotics used for Gram-positive bacteria were Cefoxitin, azithromycin, amoxicillin/clavulanic acid, imipenem, cephalexin, vancomycin, trimethoprim-sulfamethoxazole, oxacillin, penicillin and erythromycin. For Gram-negative bacteria were gentamicin, amoxicillin, norfloxacin, tetracycline, ampicillin, aztreonam, cefotaxime, imipenem, polymyxin B, amoxicillin/clavulanic acid and cefoxitin. Interpreted according to the criteria of the CLSI.[14] MultidrugResistant Organisms (MDRO) were defined as bacteria that were resistant to more than one or all classes of antibiotics.

\section{Ethical Considerations}

The study was conducted after receiving approval of Ethics Committee in RIMS, Srikakulam (Rc No. Spl/EC/08/2016) and after obtaining informed consent subjects only.

\section{Statistical Analyses}

Used SPSS 16.0 version software were applied by bar diagram and chi-square $(\chi 2)$ test a probability of 0.05 is taken as statistically significant.

\section{RESULTS}

\begin{tabular}{|c|c|c|c|c|c|c|c|c|}
\hline \multirow[t]{2}{*}{$\begin{array}{c}\text { Type of the } \\
\text { Patient }\end{array}$} & \multirow{2}{*}{$\begin{array}{l}\text { Total No. of } \\
\text { Samples } \\
\text { (Ulcers) }\end{array}$} & \multicolumn{2}{|c|}{$\begin{array}{c}\text { Culture Negative (No } \\
\text { Growth or Non- } \\
\text { Pathogens) }\end{array}$} & \multicolumn{2}{|c|}{$\begin{array}{c}\text { Culture Positive } \\
\text { (Pathogens } \\
\text { Grown) }\end{array}$} & \multirow[t]{2}{*}{$\begin{array}{l}\text { Chi- } \\
\text { Square } \\
\text { Value }\end{array}$} & \multirow[t]{2}{*}{$\begin{array}{l}\text { Degrees of } \\
\text { Freedom }\end{array}$} & \multirow[t]{2}{*}{ Probability } \\
\hline & & No. & $\%$ & No. & $\%$ & & & \\
\hline $\begin{array}{c}\text { Diabetes } \\
\text { Mellitus (DM) }\end{array}$ & 255 & 184 & 72.16 & 71 & 27.84 & \multirow[b]{2}{*}{10.4} & \multirow[b]{2}{*}{1} & \multirow[b]{2}{*}{$\begin{array}{c}0.001 \text { (Highly } \\
\text { Significant) }\end{array}$} \\
\hline $\begin{array}{l}\text { Non-Diabetes } \\
\text { Mellitus } \\
\text { (NDM) } \\
\end{array}$ & 318 & 265 & 83.33 & 53 & 16.67 & & & \\
\hline
\end{tabular}

\section{Isolation of Pathogens from Various Specimens}

A total number of ulcer samples analysed were 255,318 from Diabetes Mellitus (DM) and Non-Diabetes Mellitus (NDM) respectively. The isolates of culture positive were $71(27.84 \%), 53(16.67 \%)$ shown in Table 1 . There is a highly significant difference $(\mathrm{P}<0.001)$ between Diabetes Mellitus (DM) and Non-Diabetes Mellitus (NDM) groups.

\begin{tabular}{|c|c|c|c|c|c|c|c|}
\hline \multirow{2}{*}{$\begin{array}{l}\text { Name of the } \\
\text { Department }\end{array}$} & \multicolumn{2}{|c|}{$\begin{array}{c}\text { Diabetes Mellitus } \\
\text { (DM) }\end{array}$} & \multicolumn{2}{|c|}{$\begin{array}{c}\text { Non-Diabetes Mellitus } \\
\text { (NDM) }\end{array}$} & \multirow{2}{*}{$\begin{array}{l}\text { Chi-Square } \\
\text { Value }\end{array}$} & \multirow{2}{*}{$\begin{array}{c}\text { Degrees of } \\
\text { Freedom }\end{array}$} & \multirow{2}{*}{ Probability } \\
\hline & No. & $\%$ & No. & $\%$ & & & \\
\hline General Medicine & 39 & 54.93 & 17 & 32.08 & \multirow{4}{*}{8.49} & \multirow{4}{*}{2} & \multirow{4}{*}{$\begin{array}{c}0.014 \\
\text { (Significant) }\end{array}$} \\
\hline Dental & 18 & 25.35 & 14 & 26.42 & & & \\
\hline $\begin{array}{c}\text { Surgery, Orthopaedics } \\
\text { \& ENT }\end{array}$ & 14 & 19.72 & 22 & 41.51 & & & \\
\hline Total & 71 & 100 & 53 & 100 & & & \\
\hline
\end{tabular}


Isolation of pathogens were more in General Medicine 39 (54.93\%) and Dental Department 18 (25.35\%) in Diabetes Mellitus (DM) group; in non-diabetic group Surgery 22 (41.51\%) and General Medicine 17 (32.08\%) departments appeared to have more isolation rate as shown in Table 2 . There is a highly significant difference $(\mathrm{P}<0.05)$ between diabetes mellitus versus non-diabetes mellitus groups and various departments.

\begin{tabular}{|c|c|c|c|c|c|c|c|}
\hline \multirow[t]{2}{*}{ Type of the Patient } & \multicolumn{2}{|c|}{$\begin{array}{c}\text { Gram Positive } \\
\text { Pathogens } \\
\end{array}$} & \multicolumn{2}{|c|}{$\begin{array}{c}\text { Gram Negative } \\
\text { Pathogens }\end{array}$} & \multirow{2}{*}{$\begin{array}{c}\text { Chi-Square } \\
\text { Value }\end{array}$} & \multirow{2}{*}{$\begin{array}{l}\text { Degrees of } \\
\text { Freedom }\end{array}$} & \multirow[t]{2}{*}{ Probability } \\
\hline & No. & $\%$ & No. & $\%$ & & & \\
\hline $\begin{array}{c}\text { Diabetes Mellitus } \\
\text { (DM) }\end{array}$ & 31 & 43.66 & 40 & 56.34 & \multirow{2}{*}{1.02} & \multirow{2}{*}{1} & \multirow{2}{*}{$\begin{array}{r}0.312 \text { (Not } \\
\text { Significant) }\end{array}$} \\
\hline $\begin{array}{l}\text { Non-Diabetes } \\
\text { Mellitus (NDM) }\end{array}$ & 28 & 52.83 & 25 & 47.17 & & & \\
\hline
\end{tabular}

\section{Isolation of Pathogens by Gram Staining}

Isolation of gram negative pathogens 40 (56.34\%) were more in diabetes mellitus and gram positive pathogens 28 (52.83\%) more in non-diabetes mellitus groups respectively as shown in Table 3. There is no significant difference $(\mathrm{P}>0.05)$ between diabetes mellitus versus non-diabetes mellitus groups and gram positive versus gram negative pathogens isolation.

\begin{tabular}{|c|c|c|c|c|c|c|c|c|}
\hline \multirow{2}{*}{$\begin{array}{c}\text { Type of } \\
\text { Bacteria }\end{array}$} & \multirow{2}{*}{$\begin{array}{c}\text { Type of } \\
\text { Pathogen }\end{array}$} & \multicolumn{2}{|c|}{$\begin{array}{c}\text { Diabetes } \\
\text { Mellitus (DM) }\end{array}$} & \multicolumn{2}{|c|}{$\begin{array}{l}\text { Non-Diabetes } \\
\text { Mellitus (NDM) }\end{array}$} & \multirow{2}{*}{$\begin{array}{c}\text { Chi- } \\
\text { Square } \\
\text { Value }\end{array}$} & \multirow{2}{*}{$\begin{array}{c}\text { Degrees of } \\
\text { Freedom }\end{array}$} & \multirow[t]{2}{*}{ Probability } \\
\hline & & No. & $\%$ & No. & $\%$ & & & \\
\hline \multirow{3}{*}{$\begin{array}{c}\text { Gram positive } \\
\text { pathogens }\end{array}$} & S. aureus & 23 & 32.39 & 21 & 39.62 & \multirow{8}{*}{1.5} & \multirow{8}{*}{6} & \multirow{8}{*}{$\begin{array}{l}0.959 \text { (Not } \\
\text { Significant) }\end{array}$} \\
\hline & S. pyogenes & 5 & 7.04 & 5 & 9.43 & & & \\
\hline & Enterococcus & 3 & 4.23 & 2 & 3.77 & & & \\
\hline \multirow{4}{*}{$\begin{array}{c}\text { Gram negative } \\
\text { pathogens }\end{array}$} & Pseudomonas & 17 & 23.94 & 9 & 16.98 & & & \\
\hline & Klebsiella & 11 & 15.49 & 7 & 13.21 & & & \\
\hline & E. coli & 7 & 9.86 & 5 & 9.43 & & & \\
\hline & Proteus & 5 & 7.04 & 4 & 7.55 & & & \\
\hline \multicolumn{2}{|c|}{ Total } & 71 & 100 & 53 & 100 & & & \\
\hline \multicolumn{9}{|c|}{ Table 4. Isolation of Pathogens by Species } \\
\hline
\end{tabular}

\section{Isolation of Pathogens by Species}

Isolation of gram positive pathogen like S. aureus 23 (32.39\%), $21(39.62 \%)$ were more and gram negative classification pseudomonas 17 (23.94\%), 9 (16.98\%) in diabetes and non- diabetes mellitus groups respectively as shown in Table 4 There is no significant difference $(\mathrm{P}>0.05)$ between diabetes mellitus versus non-diabetes mellitus groups and pathogenic species.

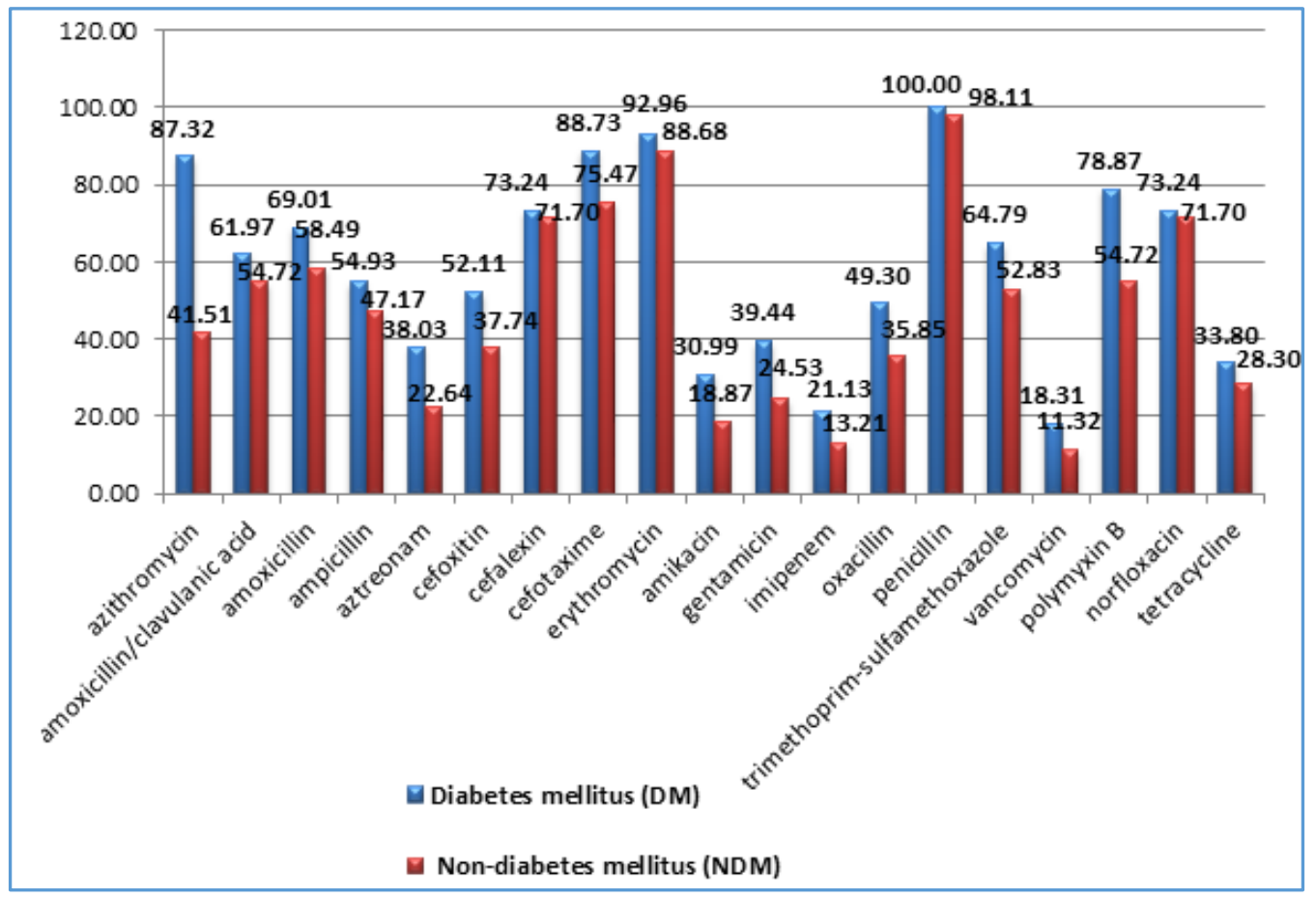

Figure 1. Antibiotic Sensitivity of Diabetes and Non-Diabetes Mellitus Pathogens 


\section{Antibiotic Sensitivity of Diabetes and Non-Diabetes Mellitus Pathogens}

In diabetic group more resistance were penicillin (100\%), azithromycin $(87.32 \%)$, cefotaxime (88.73\%), erythromycin $(92.96 \%)$ and polymyxin B (78.87\%). In non-diabetic group more resistance were cefotaxime $(75.47 \%)$, erythromycin (88.68\%) and penicillin (98.11\%) as shown in Figure 1.

\section{DISCUSSION}

The prognosis of diabetic foot infections remains poor and the outcomes have been reported to be worse with MDR pathogens than with non-MDR pathogens in patients with diabetic wound infections. [9] Our study showed more MDR strains appeared in diabetic persons who were hospitalised, chronically wounded,[12,15] and few patients underwent some type of amputation. However, wound infections are associated with mono or polymicrobial infections. Moderate-to-severe infections often necessitate empirical regimens with activity against commonly isolated gram-negative bacilli, MRSA and perhaps Enterococcus spp.[16]

The rate of wound infections vary widely between institutions, areas and site of infection. The current study showed more Multidrug Resistance (MDR) strains found in diabetic group. Mild infections are often managed with local wound care strategies and/or prophylactic measures. It is important to note that the decisions relating to the antibiotic treatment of wounds are influenced by clinical evidence, the availability of appropriate antibiotic interventions, patient's requirement and practitioner's expertise.[18]

This study is limited by the aerobic bacteria evaluation, but anaerobic bacteria could not be investigated. Wound infections often associated with aerobic pathogens majorly[17,18,19,20] and evaluated gram-positive bacteria were predominant in diabetic wound infections, in case of nondiabetic wound infections gram negative bacterium were more similar findings also mentioned by Abdulrazak et al, Wang et al and Urvish et al.[21,22,23]

The study revealed diabetic wound infections are associated with MDR strains of gram positive and gram negative pathogens and were resistant to routine antibiotics. Pseudomonas, Staphylococcus and Streptococcus infections were predominant in diabetic persons. [24,25] Possible reasons for these differences by hypoxia, hyperglycaemia, etc., longer duration of infection, more frequent hospital exposures and extended periods of antibiotic use, all of which can influence shifts in the wound microbiota.

Moreover, Proteus spp. was resistant to all betalactamics except imipenem, cefoxitin and gentamicin. Proteus spp. are known to produce a unique $\beta$-lactamase that has high activity against antibiotics, primarily cefotaxime ${ }^{[26]}$ a third-generation cephalosporin. Furthermore, Escherichia coli were resistant to the majority of antibiotics tested, except gentamicin and imipenem.[27,28]

\section{CONCLUSION}

The present study report has some limitations, because cultures for aerobic bacteria could be performed and diabetic wound infections were predominantly due to gram-negative bacteria. Antibiotic resistance rate more in diabetic persons prone for variety of infections when compared with nondiabetic mellitus. Amikacin, aztreonam, gentamicin, vancomycin, tetracycline and imipenem were the most effective antibiotics against almost all bacteria in both groups.

\section{Acknowledgments}

We thank our CSRMO Dr. Bch. Appalanaidu MBBS, this study was supported grants from: Rajiv Gandhi Institute of Medical Sciences (RIMS), Srikakulam, Andhra Pradesh - 532001, India.

\section{REFERENCES}

1. Atkins RC, Zimmet P. Diabetic kidney disease: act now or pay later. Saudi J Kidney Dis Transpl 2010;21(2):217-21.

2. Geerlings SE, Hoepelman AI. Immune dysfunction in patients with diabetes mellitus (DM). FEMS Immunol Med Microbiol 1999;26(3-4):256-65.

3. Muller LM, Gorter KJ, Hak E, et al. Increased risk of common infections in patients with type 1 and type 2 diabetes mellitus. Clin Infect Dis 2005;41(3):281-8.

4. Peleg AY, Weerarathna T, McCarthy JS, et al. Common infections in diabetes: pathogenesis, management and relationship to glycaemic control. Diabetes Metab Res Rev 2007;23(1):3-13.

5. Prevention CfDCa, National diabetes fact sheet: National estimates and general information on diabetes and prediabetes in the United States, 2011. Department of Health and Human Services, Centers for Disease Control and Prevention, Atlanta, Ga, USA, 2011.

6. Kandemir 0, Akbay E, Sahin E. et al. Risk factors for infection of the diabetic foot with multi-antibiotic resistant microorganisms. Journal of Infection 2007;54(5):439-45.

7. Richard JL, Sotto A, Jourdan N, et al. Risk factors and healing impact of multidrug-resistant bacteria in diabetic foot ulcers. Diabetes and Metabolism 2008;34(4):363-9.

8. Hartemann-Heurtier A, Robert J, Jacqueminet S, et al. Diabetic foot ulcer and multidrug-resistant organisms: risk factors and impact. Diabetic Medicine 2004;21(7):710-15.

9. Lipsky BA, Berendt AR, Deery HG, et al. Diagnosis and treatment of diabetic foot infections. Clin Infect Dis 2004;39(7):885-910.

10. Lavery LA, Armstrong DG, Murdoch DP, et al. Validation of the Infectious Diseases Society of America's diabetic foot infection classification system. Clin Infect Dis 2007;44(4):562-5.

11. Hobizal KB, Wukich DK. Diabetic foot infections: current concept review. Diabet Foot Ankle 2012:3. doi. 10.3402/dfa. v3i0.18409.

12. Woods GL. Gram-Positive Cocci, Part 1: Staphylococciand related Gram-Positive Cocci. In: Koneman EW. edr. Koneman'scolor atlas and textbook of diagnostic microbiology. $6^{\text {th }}$ edn. USA: Lippincott Williams and Wilkins 2005:624-62.

13. Clinical and Laboratory Standards Institute (CLSI). Performance standards for antimicrobial susceptibility testing: twenty-first informational supplement. M100-S21. Wayne, PA: CLSI 2011.

14. Clinical and Laboratory standards institute (clsi). Suggested grouping of US-FDA approved antimicrobial agents that should be considered for routine testing and reporting on nonfastidious organisms by clinical laboratories, M100-S23. Wayne, PA: CLSI 2013.

15. Lipsky BA, Aragón-Sánchez J, Diggle M, et al. On behalf of the International Working Group on the Diabetic Foot. (IWGDF). 2015. 
16. Gottrup F, Apelqvist J, Bjansholt T, et al. EWMA document: antimicrobials and non-healing wounds. Evidence, controversies and suggestions. J Wound Care 2013;22 (Supl 5):S1-89.

17. Senneville E, Melliez H, Beltrand E, et al. Culture of percutaneous bone biopsy specimens for diagnosis of diabetic foot osteomyelitis: concordance with ulcer swab cultures. Clin Infect Dis 2006;42(1):57-62.

18. González CFJ, Alramadan M, Matesanz M, et al. Infections in diabetic foot ulcers. Eur J Intern Med 2003;14(5):341-3.

19. El-Tahawy AT. Bacteriology of diabetic foot infections. Saudi Medical J 2000;21(4):344-7.

20. Abdulrazak A, Bitar ZI, Al-Shamali AA, et al. Bacte-riological study of diabetic foot infections. J Diab Comp 2005;19(3): 138-41.

21. Trivedi U, Parameswaran S, Armstrong A, et al. Prevalence of multiple antibiotic resistant infections in diabetic versus nondiabetic wounds. Journal of Pathogens Article ID 173053, 2014;2014:6.

22. Wang SH, Sun ZL, Guo YJ, et al. Meticillin-resistant Staphylococcus aureus isolated from foot ulcers in diabetic patients in a Chinese care hospital: risk factors for infection and prevalence. J Med Microbiol 2010;59(Pt 10):1219-24.
23. Tentolouris N, Petrikkos G, Vallianou N, et al. Prevalence of methicillin-resistant Staphylococcus aureus in infected and uninfected diabetic foot ulcers. Clin Microbiol Infect 2006;12(2):186-9.

24. Basu S, RamchuranPanray T, Singh BT, et al. A prospective, descriptive study to identify the microbiological profile of chronic wounds in outpatients. Ostomy Wound Management 2009;55(1):14-20.

25. Price LB, Liu CM, Melendez JH, et al. Community analysis of chronic wound bacteria using 16S rRNA gene-based pyrosequencing: impact of diabetes and antibiotics on chronic wound microbiota. PLoS ONE Article ID e6462, 2009:4(7).

26. Senior BW, Morganella P. Providencia. In: Balows A, Duerden BI. eds. Topley and Wilson's microbiology and microbial infections. 9th edn. London: Arnold 1998: 1035-50.

27. Umadevi S, Kumar S, Joseph NM, et al. Microbiological study of diabetic foot infections. Indian J Med Specialities 2011;2(1):12-17.

28. Anandi C, Alaguraja D, Natarajan V, et al. Bacteriology of diabetic foot lesions. Ind J Med Microbiol 2004;22(3): 175-8. 